DOI: $10.17569 /$ tojqi. 505686

Research Article

\title{
A Study on the Use of Suggestion Strategies among Turkish EFL Learners
}

\author{
Tuğba Elif Toprak Yıldız1
}

\begin{abstract}
Pragmatic competence can be regarded as one of the pillars of language competence and it involves the effective use of speech acts, which can be defined as carrying out actions through utterances. In second/foreign language contexts, using speech acts effectively grows highly significant mainly for two reasons: i) speech acts are fundamental to communication, ii) speech acts reflect the basic social norms and cultural values of the target speech community. Although speech acts such as requests, apologies and refusals have been investigated in a plethora of studies, suggestions have received relatively limited scholarly attention in the English as a second/foreign language (ESL/EFL) contexts, and in particular, in a writing medium. As such, this qualitative study aims to investigate how Turkish EFL adult learners suggest in English in a writing medium. The data were collected by using a scenario-based task which helped elicit how the participants suggested and what kind of linguistic strategies and elements they used while making suggestions. The results of the qualitative content analysis demonstrated that the most commonly used suggestion type was "conventionalized" whereas "direct strategies" remained scarce. Moreover, it was found that the participants mostly used "possibility" and "should" as suggestion strategies. Overall, the findings suggested that the participants tried to render their suggestions as less face-threatening as possible by lessening the degree of imposition placed on the hearer while being as cooperative as possible, a tendency which can be deduced from the frequent use of "we can" structure.
\end{abstract}

Keywords: Second/foreign language learning, pragmatic competence, speech acts, suggestions, Turkish EFL learners.

\footnotetext{
${ }^{1}$ Asst.Prof.Dr., Izmir Democracy University, Faculty of Letters, Department of English Language and Literature, tugbaeliftoprak@gmail.com, https://orcid.org/0000-0003-0341-229X.
} 


\title{
İngilizce’yi Yabancı Dil Olarak Öğrenen Türk Öğrencilerin Öneri Sözeylem Stratejileri Kullanımı
}

\begin{abstract}
Özet
Dil yeterliğinin temel bileşenlerinden biri olarak kabul edilen edimbilimsel yeterlik, sözeylemleri etkili kullanabilme becerisini içerir. İkinci/yabancı dil bağlamında, sözeylemlerin etkili bir biçimde kullanılması esas olarak iki nedenden ötürü önemlidir: i) sözeylemler iletişimin temel yapı taşlarından biridir, ii) sözeylemler hedef konuşma topluluğunun temel sosyal normlarını ve kültürel değerlerini yansıtmaktadır. Talep etme, özür dileme ve reddetme gibi sözeylemler pek çok çalışmada incelenmiş olsa da öneride bulunma sözeylemi ikinci/yabancı dil bağlamında ve özellikle yazma ortamında nispeten sınırlı sayıda çalışmada ele alınmıştır. Bu nitel çalışma, yetişkin Türk öğrencilerin öneri sözeylemini İngilizce'de yazılı ortamda nasıl gerçekleştirdiklerini irdelemektedir. Nitel veri, katılımcıların nasıl öneride bulunduklarını ve bu önerilerde ne tür dil stratejileri ve unsurlarını kullandıklarını anlamayı amaçlayan senaryo bazlı bir iletişimsel etkinlik kullanılarak toplanmıştır. Nitel içerik analizinin sonuçlarına göre, en sık kullanılan öneri stratejisi türü "konvensiyonelleştirilmiş" stratejiler iken, "doğrudan" stratejiler ise sınırlı sayıda kullanılmıştır. Ayrıca, katılımcıların öneri stratejisi olarak çoğunlukla olasılık ve gereklilik bildiren yapıları kullandıkları saptanmıştır. Buna ek olarak, katılımcıların mümkün olduğunca işbirlikçi bir söylemde bulundukları ve iletişim kurulan kişiye yöneltilen dayatmayı daha az tehdit edici hale getirmeye çalıştıkları katılımcıların sıklıkla kullandığ 1 "yapabiliriz" yapısından da anlaşılmaktadır.
\end{abstract}

Anahtar Kelimeler: İkinci/yabancı dil ögrenimi, edimbilimsel yeterlik, sözeylemler, yetişkin Ingilizce ögrencileri. 


\section{Introduction}

Pragmatic competence can be regarded as one of the pillars of language competence along with the organizational competence which entails grammatical and textual knowledge (Bachman, 1990). The notion of pragmatic competence includes knowledge and skills that language learners need to operate in a particular cultural and social context and the knowledge of linguistic elements that help realize a particular speech act. Speech acts, which can be defined as doing actions by means of utterances, are the crucial components of pragmatic competence (Schmidt \& Richards, 1980). Typical examples of speech acts would be claiming, requesting, promising, refusing and apologizing. Language users and learners need to be equipped with sociopragmatic and sociolinguistic competence to effectively utilize speech acts for communicative purposes (Leech, 1983). Sociopragmatic competence entails the knowledge of what speech act is appropriate in a specific situation and when to perform it, while sociolinguistic competence involves the knowledge of linguistic features to conduct a particular speech act. In other words, a language user needs to know i) what speech acts is appropriate in the context at hand, ii) what strategies are needed for conducting the speech act of interest and iii) what lexical and grammatical properties are needed for realizing the speech act.

Due to their centrality to second/foreign language competence, speech acts have been explored in a significant number of studies conducted in ESL/EFL contexts to understand how English language learners perform speech acts. There has been a growing body of literature on ESL/EFL apologies (e.g., Bergman \& Kasper, 1993; Chang, 2010; Cohen \& Olshtain, 1981; Dalmau \& Gotor, 2007; Kondo, 1997; Mir, 1992; Trosborg, 1987; Ugla \& Abidin, 2016), complaints (e.g., Bikmen \& Mart1, 2013; Boxer \& Pickering, 1995; Clyne, Ball, \& Neil, 1991; Deveci, 2010; Martínez-Flor \& Usó-Juan, 2017), and requests (e.g., Chen, 2015; Li, 2000; Gürsoy, 2011; Halenko \& Jones, 2011; Jalilifar, 2009; Kılıçkaya, 2010; Otçu \& Zeyrek, 2008; Savic, 2015; Suh, 1999; Şanal \& Ortaçtepe, 2019; Taguchi, 2006). However, despite rich literature on various speech acts, suggestions remain relatively underexplored (Jiang, 2006). This situation might be surprising considering the frequency of the act of suggesting in real life. Schmidt, Shimura, Wang, and Jeong (1995) also maintained that suggestions have attracted less attention when compared to requests, which is a cousin of suggestions and a 
frequent target of scholarly scrutiny. Apart from this relatively limited scholarly attention, the face-threatening nature of suggestions and their frequent use in daily life make this speech act a legitimate target of the inquiry.

Considering the dearth of studies dealing with suggestions in general, and in Turkish context in particular, the present study aims to investigate following research questions:

1) How do Turkish EFL (English as a Foreign Language) learners make suggestions in English in a writing medium?

2) What kinds of strategic/linguistic features do Turkish EFL learners employ to make suggestions?

To the researcher's best knowledge, so far, suggestions have not been investigated in the Turkish EFL context. Hence, it is hoped that the present study would add to the growing body of literature on L2 suggestions.

\section{Literature Review}

\section{The Nature of Suggestions}

Suggestions can be grouped under the directive and expressive speech acts (Searle, 1969). Directives encompass speech acts such as suggestions, requests, and commands whose primary goal is to get the hearer to do something. However, the degree of imposition on the hearer varies across these speech acts. For instance, Haverkate (1984) made a distinction between impositive and non-impositive speech acts by stating that while the former group includes more threatening speech acts like requesting and ordering, the latter contains suggestions which are nonimpositive. The distinction between these two groups of speech acts lies in the benefit scale. In impositive speech acts, the benefit is on the side of the speaker, on the other hand, in nonimpositive speech acts benefit is to the hearer. On this issue, Rintel $(1979$, p.99) stated that "In a suggestion, the speaker asks the hearer to take some action which the speaker believes will benefit the hearer, even one that the speaker should desire." Even though suggestions are nonimpositive and indicate a benefit to the hearer, Brown and Levinson (1987) considered suggestions as face-threatening since the speaker intrudes into the world of the hearer and this 
imposition may threaten negative face of the hearer. Moreover, Brown and Levinson (1987) stated that when suggesting, several elements, including the urgency of the suggestion, the degree of embarrassment in the situation, social distance and power relationship between the speaker and the hearer should be taken into consideration. Hence, in order not to offend the hearer or lessen the degree of impositions speakers may resort to mitigations or politeness strategies.

\section{Previous Research on Suggestions}

Speech act theory involves doing actions through utterances (Schmidt \& Richards, 1980). In the relevant literature, a number of studies have been conducted on exploring the structure and properties of various speech acts such as requests, complaints and apologies. On the contrary, the number of studies investigating suggestions in the ESL/EFL context remained relatively limited. Santos and Silva (2008) discussed the possible reasons for the relatively scant attention that suggestions have attracted and speculated that the difficulty of defining suggestions may be the culprit.

To date, Banerjee and Carrell (1988) conducted a study on 28 native speakers of Chinese or Malay and 12 native speakers of American English using a discourse completion questionnaire that included 60 situations to elicit suggestions in English. The authors aimed to find out if there were differences between the fashion that adult native speakers and nonnative speakers suggested. They demonstrated that native speakers suggested to some extent more frequently, nevertheless, nonnatives were more direct in their suggestions than their native counterparts. The study conducted by Martinez-Flor and Fukuya (2005) had a different focus. The study investigated the impact of explicit and implicit pragmatic instruction on suggestions made by adult Spanish learners of English. The findings demonstrated that both explicit and implicit groups improved regarding producing pragmatically suitable and linguistically accurate suggestions. Two studies that were conducted in the EFL environment took place in the Iranian context. Pishghadam and Sharafadini (2011) found out that modals, imperatives, to clause, and conditionals were the most used strategies, while let's was among the least commonly used strategies in the suggestions by Iranian learners of English. They also concluded that gender and language proficiency play a vital role in making suggestions. Ahmadi, Kargar, and Rostampour (2014), on the other hand, revealed that the most commonly used strategies by 
Iranian EFL learners were imperatives, conditionals, modals, yes/no questions, to clause, let's, wh questions and performatives. The findings showed there was no difference in suggestions made across three levels of proficiency and gender. Finally, Jiang (2006) aimed to investigate the linguistic forms used to make suggestions in both real language and ESL textbooks. The results demonstrated that the order of suggestions used by the native speakers of English was let's, modals, imperatives, wh-questions, conditional, pseudo-cleft, performatives, to clause and yes/no question in decreasing order. Given the scarcity of studies focusing on EFL learners' suggestions, the present study set out to investigate Turkish native speakers' suggestions in English.

\section{Methodology}

\section{The Context}

The study took place in a higher education setting where the participants learnt and used English as a foreign language. The participants were enrolled in a compulsory general English course offered in their department. The course was centered around activities that required the students to use English for communicative purposes, such as preparing a poster for a departmental event and watching a film in English and holding discussions about the film. The task that was used to elicit the participants' suggestion strategies was given to them as a requirement of this course. Although the course focused on communicative aspects of the foreign language and activities utilized were communicative in nature, the students did not receive any explicit instruction on speech acts.

\section{Participants}

The participants of the study were 65 undergraduate students attending foreign languages department of a large-sized state university located in a metropolitan city (54 female students, 11 male students). They were aged between 21-23 and all of them were native speakers of Turkish. The participants' English proficiency corresponded to B1-B2 level on the CEFR scale. Since all the students participating in the course were included in the study, a convenience sampling method was applied. 


\title{
Data Collection and Analysis
}

Conventionally, discourse completion tests (DCTs) have been extensively used in the relevant literature to collect speech act data. According to Kasper and Rose (2002), DCTs can be considered as questionnaires which help collect written production data. The instrument is designed in such a way that it includes a depiction of a situation which requires the use of a specific pragmatic aspect. However, despite their common use, DCTs have also been criticized for being artificial, test-like and cannot be compared to authentic communication (Sasaki, 1998). Hence, in the present study, a more authentic qualitative data collection tool, a scenariobased communicative task was generated following the guidelines proposed by Martinez-Flor (2005) was presented to the participants to overcome the limitations of DCTs. The scenario was as follows:

\begin{abstract}
"One of your foreign friends that you have been online friends for years sends you an e-mail and asks you that he/she plans to visit Turkey soon. Respond to your friend's e-mail and make suggestions about the visit so that s/he can make arrangements beforehand."
\end{abstract}

The participants were asked to craft an e-mail response to their friend and make suggestions about the visit, specifically about the timing, sightseeing, and possible activities. They were familiar with the concept of writing an e-mail to a friend in both in Turkish and English. Before starting to compose their e-mails, they were asked to brainstorm about and describe places that they thought worth seeing and exploring in Turkey. Then, they wrote their e-mails during the class.

The content of the e-mails were analyzed by using the qualitative content analysis technique based on the suggestions taxonomy proposed by Martinez-Flor (2005) (See Table 1). Qualitative content analysis can be described as an umbrella term for different strategies that are utilized to scrutinize texts and determine the characteristics of the content, trends, patterns and structures by posing a systematic coding and categorization approach (Vaismoradi, Turunen, \& Bondas, 2013). In the present study, suggestions were classified into three strategies that are elaborated in Table 1. 
Table 1

Taxonomy of Suggestions

\begin{tabular}{|c|c|c|}
\hline Suggestion type & Suggestion Strategy & \\
\hline \multicolumn{3}{|l|}{ Direct strategies } \\
\hline & Performative verb & "I suggest that you..." \\
\hline & Noun of suggestion & "My suggestion would be..." \\
\hline & Imperatives & "Try using..." \\
\hline & Negative imperative & "Don't try to..." \\
\hline \multicolumn{3}{|c|}{ Conventionalized forms } \\
\hline & Interrogative forms & "Why don’t you..?" \\
\hline & Possibility & "You can..." \\
\hline & Should & "You should..." \\
\hline & Need & "You need to..." \\
\hline & Conditional & "If I were you, I would..." \\
\hline \multicolumn{3}{|l|}{ Indirect Strategies } \\
\hline & Impersonal & "It might be better to..." \\
\hline & Hints & "I've heard that..." \\
\hline & Inclusive we & "Let's..." \\
\hline & Obligation & "You must..." \\
\hline
\end{tabular}

While conducting the analyses, a suitable suggestion type and a strategy were assigned to each instance detected. To illustrate, initially, "How about a music show on Friday evening?" was labeled as a suggestion. Then, based on the taxonomy, it was decided that this suggestion belonged to the suggestion type, conventionalized forms. Finally, it was concluded that this suggestion was made by using by the strategy "interrogative forms". Stated differently, for each instance identified, a three-step placement was carried out. Finally, the analysis of qualitative data was quantified through. The analyses were conducted, and strategies were coded at three different times to ensure intra-rater reliability.

\section{Findings}

This section reports on the results of the content analysis. The first research question sought how Turkish EFL learners make suggestions. The results about this question are presented in Table 2. 
Table 2

Suggestion Types Employed by the Participants

\begin{tabular}{lll}
\hline Suggestion type & Frequency & Percentage \\
\hline Conventionalized form & 132 & 84 \\
Indirect strategies & 21 & 13 \\
Direct strategies & 5 & 3 \\
Total & 158 & 100 \\
\hline
\end{tabular}

The results revealed that the most frequently used suggestion type was "conventionalized forms". "Conventionalized forms" are not direct, yet they allow the hearer to grasp the speaker's intentions behind the suggestion. Martinez-Flor (2005) maintained that strategies categorized under "conventionalized forms" exhibit a greater variety concerning linguistic realization. Second, $13 \%$ of the suggestions made were "indirect strategies" that refer to suggestions in which the intentions of the speaker are not clearly articulated. Such suggestions do not include any conventionalized forms that signal a suggestive force in the utterance. As a result, the hearer needs to infer that a suggestion is made. Finally, the number of "direct strategies" was five, corresponding to $3 \%$ of the total suggestions. In "direct strategies", the speaker clearly states what s/he suggests. Typically, these suggestions entail the use of a performative verb.

The second research question sought what kinds of linguistic realizations were employed to make suggestions. To answer this question, in each suggestion was examined in line with the strategy types elaborated on Table 1. Each suggestion type is realized through several strategies which are directly linked to a linguistic structure. Results on this research question are demonstrated in Table 3. 
Table 3

Suggestion Strategies Employed by the Participants

\begin{tabular}{|c|c|c|c|c|}
\hline Strategy & Suggestion type & Frequency & Percentage & Examples \\
\hline Possibility & $\begin{array}{l}\text { Conventionalized } \\
\text { form }\end{array}$ & 91 & 58 & $\begin{array}{l}\text { "You can buy } \\
\text { traditional } \\
\text { goods around } \\
\text { the castle of } \\
\text { Ankara." }\end{array}$ \\
\hline Should & $\begin{array}{l}\text { Conventionalized } \\
\text { form }\end{array}$ & 27 & 17 & $\begin{array}{l}\text { "I think you } \\
\text { should see } \\
\text { Antalya." }\end{array}$ \\
\hline Impersonal & $\begin{array}{l}\text { Indirect } \\
\text { strategies }\end{array}$ & 12 & 8 & $\begin{array}{l}\text { "My } \\
\text { hometown is } \\
\text { worth seeing." }\end{array}$ \\
\hline Obligations & $\begin{array}{l}\text { Indirect } \\
\text { strategies }\end{array}$ & 10 & 6 & $\begin{array}{l}\text { "You must see } \\
\text { historical } \\
\text { places in } \\
\text { Bursa." }\end{array}$ \\
\hline Conditionals & $\begin{array}{l}\text { Conventionalized } \\
\text { form }\end{array}$ & 5 & 3 & $\begin{array}{l}\text { "If I were you, } \\
\text { I would come } \\
\text { to Istanbul." }\end{array}$ \\
\hline $\begin{array}{l}\text { Interrogative } \\
\text { forms }\end{array}$ & $\begin{array}{l}\text { Conventionalized } \\
\text { form }\end{array}$ & 5 & 3 & $\begin{array}{l}\text { "Why don't } \\
\text { you come to } \\
\text { Istanbul?" }\end{array}$ \\
\hline Performative & Direct strategies & 3 & 2 & $\begin{array}{l}\text { "I suggest that } \\
\text { you visit my } \\
\text { cute } \\
\text { hometown } \\
\text { Isparta." }\end{array}$ \\
\hline Imperative & Direct strategies & 3 & 2 & $\begin{array}{l}\text { "Come and } \\
\text { taste our } \\
\text { traditional } \\
\text { meals!" }\end{array}$ \\
\hline Inclusive we & $\begin{array}{l}\text { Indirect } \\
\text { strategies }\end{array}$ & 1 & 1 & $\begin{array}{l}\text { "Let's have } \\
\text { some fun!" }\end{array}$ \\
\hline Total & & 157 & 100 & \\
\hline
\end{tabular}

The results revealed that the most commonly used strategy was "possibility" by far (91 instances). Typically, this strategy features the use of models such as "can", "could" and "may". In conventionalized forms, possibility "can" was the most dominant structure used to realize suggestions except for a few cases in which "may" was used. Below, several extracts taken from the e-mails are presented. 
"We can eat the most delicious kumpir in Ortaköy."

"You can visit Hagia Sophia, Blue Mosque and Topkapı Palace and a lot of historical buildings."

"We can go to Mount Erciyes, have a picnic, get on the aerial tramway and eat mantr."

"You can go skiing, take a walk near the lake surrounded by mountain pines which have all the tones of green."

"If you come here this summer, we can go on a picnic around Göksu and Mogan Lake."

"You can visit the Grand Bazaar in Istanbul."

One striking feature about this strategy is that, in the majority of instances, speakers used the plural pronoun "we" instead of "you", a situation that signals a collectivist attitude. Likewise, by using possibility "can" in 53 instances out of 91 instances, the participants used utterances beginning "We can ...", reflecting a collectivist attitude. Moreover, in some cases, the speakers directly included themselves in the suggested action by using the first personal pronoun "I". Below, there are some extracts illustrating this observation.

"Maybe I can help you with choosing your destination."

"If you come to Istanbul, I can show you around."

"If you prefer Izmir, I can cook delicious meals for you."

"If you decide to come to Ankara, I can help you during your visit, and we can go everywhere."

"I can take you to coffee-houses where we can taste a special coffee called mirra."

The second most used strategy was "should", another conventionalized form. Below, there are examples illustrating how this strategy was used by different participants.

"Gaziantep has a dessert called baklava. You should taste it!"

"You should see Çorum because you earlier said that historical places attract you."

"If you come to Turkey, I think you should see Safranbolu, which is a very beautiful place attracting lots of tourists." 
"You should see the Galata Tower."

"You should come to Trabzon and experience its attractive atmosphere."

The third most frequently used strategy was "impersonal", an indirect suggestion type. Using impersonal suggestions has been a way to make indirect and face-saving suggestions in which the speaker offers the hearer greater space to avoid or dismiss the suggestion made. Below, a few examples of these suggestions have been presented.

"If you want to have a rest, Uzungöl is the best place."

"There are many wonderful places to visit in İstanbul such as Hagia Sophia, the Grand Bazaar, Istiklal Street."

"If you don't like visiting museums, there are several concert halls for classical music and opera."

"If you want to go shopping, there are lots of shopping centers in Trabzon."

The fourth most frequently used strategy was obligation, which was usually expressed by using "must". This strategy was used ten times.

"I think you must visit Eminönü and eat fish."

“You must see Gaziantep.”

"You must come to Ankara."

Apart from these strategies, conditionals as in "If I were you, I would spend my holiday in Balıkesir", interrogative forms as in "Why don't you join me?", performatives as in "I suggest you go to a seaside resort", imperatives as in "Come and visit me and we have a good time together" and inclusive we as in "Let's have some fun" were used by the participants in a few instances.

\section{Discussions and Conclusions}

The present study aimed to investigate how Turkish EFL learners make suggestions in English and in the writing medium by scrutinizing suggestion types and linguistic properties of the 
suggestion strategies. Especially, investigating suggestions in the writing medium by using an authentic task is significant in that most research efforts in the literature have opted for structured DCTs for data collection. The first research question sought how Turkish EFL learners make suggestions. In other words, it investigated what type of suggestions (i.e., direct, conventionalized and indirect) they used. The second research question sought what kinds of strategies and linguistic elements were employed to express suggestions at the micro level. Pertaining to the first research question, the results demonstrated that the most frequently used suggestion type was "conventionalized". The participants did not prefer using "direct" suggestions which could be regarded as face-threatening by the hearers. Although social distance and power was not a concern in the scenario at hand, the majority of the participants opted for using "conventionalized" suggestions. The number of "indirect" suggestions, in which the hearer infer the suggestion himself/herself was extremely scarce. The results also demonstrated that the participants avoided being forceful or pushy by using the "direct" suggestions. They used the "conventionalized" suggestions which exhibit greater linguistic variety (Martinez-Flor, 2005), include elements that lessen the degree of imposition on speakers, and protect the hearer's face.

Pertaining to the second research question, the results indicated that the most commonly used suggestion strategy was "possibility". The participants specifically included modals such as "can" and "may" to mitigate the force of their suggestions. Since suggestions can communicate an authoritative tone, the participants may have resorted to such structures to soften the impact. The order of most commonly used strategies was as follows; "possibility", "should", "impersonal", “obligations", "conditionals", "interrogative forms", "performative", "imperative" and "inclusive we" (let's). Of interest, the study conducted on Iranian EFL speakers by Pishghadam and Sharafadini (2011) revealed that modals were the most used strategy, while "let's", in other words, "inclusive we" was among the least commonly used strategies. These findings of the present study seem to concur with the findings of Pishghadam and Sharafadini (2011) since there were resemblances between the most frequently used strategies across studies: the frequent use of modals and the absence of inclusive we, i.e., "let's". On the other hand, Ahmadi, Kargar, and Rostampour (2014) found out that the participants mostly used "imperatives", "conditionals", "modals", "yes/no questions" in decreasing order to make suggestions. This finding is not in line with the findings of the present study since the most frequently used strategies differed across studies. However, this is quite understandable 
since the contexts and frameworks of the studies were different. Finally, the findings of the present study partly concur with Jiang (2006) who explored suggestions made by American speakers of English. Jiang (2006) listed inclusive we, modals and imperatives as the most commonly used strategies. In the present study, possibility (can, could) and should were the most commonly used strategies while inclusive we and imperatives remained scarce. Thus, it can be deduced that there are commonalities and discrepancies between the findings of the two studies.

Overall, the findings of the present study revealed that the participants mostly used "conventionalized forms", specifically modals, to make suggestions. Suggestion strategies used by the participants were not as direct as the ones used by American or Iranian speakers of English who opted for more direct strategies. Turkish speakers of English tended to be as cooperative as possible, which can be deduced from the use of "we can" structure. They also tried to make their suggestions as less face-threatening as possible by lessening the degree of imposition placed on the hearer. Hence, it can be inferred that Turkish speakers of English in the present study generally applied negative politeness principles proposed by Brown and Levinson (1987). According to Brown and Levinson (1987), negative politeness strategies are applied to mitigate the impact of imposition made on the hearer by offering the hearer more space to avoid the suggestion. Typical strategies to achieve this goal would include being indirect, employing questions and hedging, minimizing the imposition and giving deference. In the present study, the participants seemed to avoid direct suggestion strategies to sound less pushy. However, they also did not employ indirect suggestion strategies to avoid being regarded as uninterested, uncaring or uncooperative. Therefore, conventionalized forms seemed to be a plausible option for meeting these conditions.

Suggestions made by the participants exhibited some degree of linguistic variety. Nevertheless, the extent of variety reflected in the suggestions could be enhanced. The literature on pragmatic development also indicates that pragmatic competence may not go hand in hand with overall language development, specifically with grammatical development (Bardovi-Harlig and Dörnyei, 1998). Furthermore, pragmatic failures or inefficiencies can be encountered even during the comprehension and production process of advanced foreign language learners (Blum- Kulka, House, \& Kasper, 1989). To address these concerns, increasing attention has been paid to incorporating pragmatics into language teaching (e.g., Alcon Soler, 2005; Koike 
\& Pearson, 2005; Takimoto, 2009). Results from the relevant literature demonstrated that language learners benefit from the teaching of pragmatics. Even though the present study did not employ an experimental design in which the impact of pragmatic instruction was investigated, the findings of the study revealed that there was a need for pragmatic instruction since the participants mainly opted for a limited range of suggestion strategies. Thus, it could be implicated that foreign language learners could benefit from targeting at pragmatic competence through the use of authentic language samples which showcase how pragmatic elements are used in real communication. Specifically, activities which help language learners understand, practice and produce pragmatic elements, and activities that raise learners' pragmatic awareness could prove useful if implemented at early stages of language learning.

When conclusions are drawn from the findings of the present study, the following limitations need to be taken into account since they also point to future possible research directions. First, the qualitative data collected were based solely on a scenario-based writing task. Although this task was authentic and communicative and proved to be effective in yielding rich qualitative data, future studies could diversify the data collection tools. Moreover, future studies could investigate sociopragmatic features across the first and second/foreign language performances to understand whether there is a pragmatic transfer between the two languages. Finally, the sample of the present study was limited to a group of undergraduate students learning English in an academic EFL context. Future research may also investigate the use of suggestions in nonacademic contexts across different age and proficiency groups. 


\section{References}

Ahmadi, M., Kargar, A. A., \& Rostampour, M. (2014). Investigating the role of gender, proficiency level and 11 on Iranian EFL learners' production of suggestion speech act. International Journal of Language Learning and Applied Linguistics World, 6(3), 163180.

Bachman, L. (1990). Fundamental considerations in language testing. Oxford: Oxford University Press.

Banerjee, J., \& Carrell, P. L. (1988). Tuck in your shirt, you squid: Suggestions in ESL. Language Learning, 38(3), 313-364.

Bardovi-Harlig, K., \& Dörnyei, Z. (1998). Do language learners recognize pragmatic violations? Pragmatic versus grammatical awareness in instructed L2 learning. TESOL QUARTERLY, 32(2), 233-259.

Barnlund, D. C., \& Yoshioka, M. (1990). Apologies: Japanese and American styles. International Journal of Intercultural Relations, 14(2), 193-206.

Bergman, M. L., \& Kasper, G. (1993). Perception and performance in native and nonnative apology. Interlanguage Pragmatics, 4(1), 82-107.

Bikmen, A., \& Martı, L. (2013). A study of complaint speech acts in Turkish learners of English. Education and Science, 38(170), 253-265.

Blum-Kulka, S., \& Olshtain, E. (1984). Requests and apologies: A cross-cultural study of speech act realization patterns (CCSARP). Applied Linguistics, 5(3), 196-213.

Blum-Kulka, S., House, J., \& Kasper, G. (1989). Cross-cultural pragmatics: Requests and apologies. Norwood, NJ: Ablex.

Boxer, D., \& Pickering, L. (1995). Problems in the presentation of speech acts in ELT materials: The case of complaints. ELT Journal, 49, 44-58.

Brown, P., \& Stephen, C. L. (1987): Politeness: Some universals in language use. Cambridge: Cambridge University Press.

Chang, Y. F. (2010). 'I no say you say is boring': The development of pragmatic competence in L2 apology. Language Sciences, 32(3), 408-424. 
Chen, Y. S. (2015). Developing Chinese EFL learners' email literacy through requests to faculty. Journal of Pragmatics, 75, 131-149.

Clyne, M., Ball, M., \& Neil, D. (1991). Intercultural communication at work in Australia: Complaints and apologies in turns. Multilingua-Journal of Cross-Cultural and Interlanguage Communication, 10(3), 251-274.

Cohen, A. D., \& Olshtain, E. (1981). Developing a measure of sociocultural competence: The case of apology. Language Learning, 31(1), 113-134.

Dalmau, M. S., \& Gotor, H. C. (2007). Form "sorry very much" to "I'm ever so sorry": Acquisitional patterns in L2 apologies by Catalan learners of English. Intercultural Pragmatics, 4(2), 287-315.

Deveci, T. (2010). The use of complaints in the inter-language of Turkish EFL learners. Colombian Applied Linguistics Journal, 12(2), 25-42.

Eslami-Rasekh, A., \& Mardani, M. (2010). Investigating the effects of teaching apology speech act, with a focus on intensifying strategies, on pragmatic development of EFL learners: The Iranian context. The International Journal of Language Society and Culture, 30(1), 96-103.

Gürsoy, E. (2011). The effect of textbooks on ELT trainees' use of pragmalinguistic features. Novitas-ROYAL, 5(2), 247-264.

Halenko, N., \& Jones, C. (2011). Teaching pragmatic awareness of spoken requests to Chinese EAP learners in the UK: Is explicit instruction effective?. System, 39(2), 240-250.

Haverkate, H. (1984). Speech acts, speakers and hearers. Pragmatics and beyond 4. Amsterdam: John Benjamins.

Jalilifar, A. (2009). Request strategies: Cross-sectional study of Iranian EFL learners and Australian native speakers. English Language Teaching, 2(1), 46-61.

Kasper, G., \& Rose, K. R. (2002) Pragmatic development in a second language. Malden, MA: Blackwell.

Kilıçkaya, F. (2010). The pragmatic knowledge of Turkish EFL students in using certain request strategies. Social Sciences Journal of Gaziantep University, 9(1), 185-201. 
Koike, D. A., \& Pearson, L. (2005). The effect of instruction and feedback in the development of pragmatic competence. System, 33(3), 481-501.

Kondo, S. (1997). The development of pragmatic competence by Japanese learners of English: Longitudinal study on interlanguage apologies. Sophia linguistica: Working papers in linguistics, (41), 265-284.

Leech, G. N. (1983). Principles of Pragmatics. London: Longman.

$\mathrm{Li}$, D. (2000). The pragmatics of making requests in the L2 workplace: A case study of language socialization. Canadian Modern Language Review, 57(1), 58-87.

Martínez-Flor, A. (2005). A theoretical review of the speech act of suggesting: towards a taxonomy for its use in FLT. Revista Alicantina de Estudios Ingleses, 18, 167-187.

Martínez-Flor, A., \& Fukuya, Y. J. (2005). The effects of instruction on learners' production of appropriate and accurate suggestions. System, 33(3), 463-480.

Martínez-Flor, A., \& Usó-Juan, E. (2017). The Long-term Effects of Instruction on EFL Learners' Use of Complaining Formulas. EPiC Series in Language and Linguistics, 2, 69-74.

Mir, M. (1992). Do We All Apologize the Same? An Empirical Study on the Act of Apologizing by Spanish Speakers Learning English. Pragmatics and Language Learning, 3, 1-19.

Otçu, B., \& Zeyrek, D. (2008). Development of requests: A study on Turkish learners of English. In M. Pütz, \& J. N. Aertselaer, (Eds.), Developing contrastive pragmatics interlanguage and cross-cultural perspectives (pp. 265-298). Berlin: Mouton de Gruyter.

Pishghadam, R., \& Sharafadini, M. (2011). A Contrastive Study into the Realization of Suggestion Speech Act: Persain vs English. Canadian Social Science, 7(4), 230-239.

Rintell, E. (1979). Getting your speech act together: The pragmatic ability of second language leamers. Working Papers on Bilingualism,17, 97-10.

Savić, M. (2015). “Can I very please borrow it?”: Request development in young Norwegian EFL learners. Intercultural Pragmatics, 12(4), 443-480.

Santos, D., \& Silva, G. V. (2008). Making suggestions in the workplace: Insights from learner and native speaker discourses. Hispania, 651-664. 
Sasaki, M. (1998). Investigating EFL students' production of speech acts: A comparison of production questionnaires and role plays. Journal of Pragmatics, 30, 457-484.

Schlenker, B. R., \& Darby, B. W. (1981). The use of apologies in social predicaments. Social Psychology Quarterly, 271-278.

Schmidt, R. W., \& Richards, J. C. (1980). Speech acts and second language learning. Applied Linguistics, 1(2), 129-157.

Schmidt, R., Shimura, A., Wang, Z., Jeong, H. (1995). Suggestions to buy: Television commercials from the US, Japan, China and Korea. In: Gass, S., Neu, J. (Eds.), Speech Acts across Cultures: Challenges to Communication in a Second Language. Mouton de Gruyter, New York, pp. 285-316.

Searle, J. (1969). Speech Acts: An Essay in the Philosophy of Language. Cambridge University Press, Cambridge.

Soler, E. A. (2005). Does instruction work for learning pragmatics in the EFL context?. System, $33(3), 417-435$.

Suh, J. S. (1999). Pragmatic perception of politeness in requests by Korean learners of English as a second language. IRAL-International Review of Applied Linguistics in Language Teaching, 37(3), 195-214.

Şanal, M., \& Ortaçtepe, D. (2019). Conceptual socialization in EFL contexts: A case study on Turkish EFL learners' request speech acts realization. Journal of Language and Linguistic Studies, 15(1), 376-399.

Taguchi, N. (2006). Analysis of appropriateness in a speech act of request in L2 English. Pragmatics, 16(4), 513-533.

Takimoto, M. (2009). Exploring the effects of input-based treatment and test on the development of learners' pragmatic proficiency. Journal of Pragmatics, 41(5), 10291046.

Trosborg, A. (1987). Apology strategies in natives/non-natives. Journal of Pragmatics, 11(2), $147-167$.

Ugla, R. L., \& Abidin, M. J. Z. (2016). A Study of Apology Strategies Used by Iraqi EFL University Students. International Journal of Evaluation and Research in Education, 5(1), 32-38. 
Vaismoradi, M., Turunen, H., \& Bondas, T. (2013). Content analysis and thematic analysis: Implications for conducting a qualitative descriptive study. Nursing \& Health Sciences, 15(3), 398-405. 